\title{
Dimorphism in Quaternary Scelidotheriinae (Mammalia, Xenarthra, Phyllophaga)
}

\author{
Ángel R. Miño-Boilini and Alfredo E. Zurita
}

\begin{abstract}
The contributions concerning possible cases of sexual dimorphisms in fossil and living sloths are scarce. Until now, studies in fossil ground sloth sexual dimorphism have been limited to the subfamilies Megatheriinae (Eremotherium) and Mylodontinae (Paramylodon) from the Pliocene and Pleistocene of South America and North America. Scelidotheriinae constitutes an endemic lineage of ground sloths from South American, with a biochron age ranging the lapse "Friasian"-Lujanian SALMAs (middle Miocene-early Holocene). An integral phylogenetic and taxonomic revision of the Quaternary Scelidotheriinae shows that it is possible to recognize three genera and six species: Scelidotherium Owen (Scelidotherium leptocephalum and S. bravardi), Valgipes Gervais (Valgipes bucklandi), and Catonyx Ameghino (Catonyx cuvieri, C. tarijensis, and $C$. chiliensis). One of the most noticeable aspects in some specimens analyzed $(n=47)$ was the presence of two morphtypes in each species at the level of the dorsal crests of the skull (parasagittal crests and sagittal crest) and at the level of the distal-most region of the mandible (only in C. tarijensis). In all but two species ( $S$. leptocephalum and $S$. bravardi) the two types involve the absence and presence of a sagittal crest. We suggest that specimens with sagittal crest are males, and specimens lacking sagittal crest are females. This represents the third reported ground sloth clade with evidence of sexual dimorphism of the skull and mandible.
\end{abstract}

Ángel R. Miño-Boilini. Centro de Ecología Aplicada del Litoral (CECOAL-CONICET) y Facultad de Ciencias Exactas y Naturales y Agrimensura, Universidad Nacional del Nordeste. Ruta 5, km 2,5 (CP 3400, CC 128) Corrientes, Argentina angelmioboilini@yahoo.com.ar Alfredo E. Zurita. Centro de Ecología Aplicada del Litoral (CECOAL-CONICET) y Facultad de Ciencias Exactas y Naturales y Agrimensura, Universidad Nacional del Nordeste. Ruta 5, km 2,5 (CP 3400, CC 128) Corrientes, Argentina azurita@cecoal.com.ar

Keywords: Ground sloths; Mylodontidae; South America; variability; skull; mandible

PE Article Number: 18.1.12A

Copyright: Society for Vertebrate Paleontology March 2015

Submission: 30 September 2013. Acceptance: 26 February 2015

Miño-Boilini, Ángel R. and Zurita, Alfredo E. 2015. Dimorphism in Quaternary Scelidotheriinae (Mammalia, Xenarthra, Phyllophaga). Palaeontologia Electronica 18.1.12A: 1-16.

palaeo-electronica.org/content/2015/1102-dimorphism-in-scelidotheriinae 


\section{INTRODUCTION}

Sexual dimorphism (i.e., differences in form between males and females belonging to the same species) is a widespread attribute in extant mammals (Ralls, 1977; Smith and Fisher, 2013), mainly represented by differences in body size (Isaac, 2005), but also including coloration, horns, and antlers (McDonald, 2006). In most species, males are larger than females. However, the existence of taxa in which females are larger has also been reported (e.g., Ralls, 1977; Lara-Ruiz and Chiarello, 2005).

Until now, most of the contributions on sexual dimorphism in extant mammals were limited to northern hemisphere taxa, whereas studies in tropical regions and the southern hemisphere were scarce (Isaac, 2005). Sexual dimorphism has recently been postulated for several extinct taxa, especially dinosaurs and mammals (Barden and Maidment, 2011; Smith and Fisher, 2013). This involves differences in body size and osteological characters (McDonald, 2006). McDonald (2006) and Czerwonogara and Fariña (2013) have recently suggested that the recognition of sexual dimorphism in extinct taxa could allow for the inference of some aspects of the ethological and social structure of populations under study. Sexual dimorphism also has taxonomic implications, because several species or subspecies may be actually based on males and females (see Kurtén, 1969; Frailey, 1986; McDonald, 2006).

Among mammals, the orders Artiodactyla, Carnivora, and Primates constitute the paradigmatic groups concerning studies on sexual dimorphism (including morphological and ethological differences), and thus have been used as analogous models for other groups of extinct mammals. However, as mentioned by McDonald (2006), one key question is whether these groups can be used to interpret possible sexual dimorphism in other clades such as ground sloths.

The order Xenarthra is a particular group of placental mammals, characteristic of the Neotropical region, and restricted to the American continent (Rose and Gaudin, 2010). This group includes three large clades: Cingulata (armadillos), Vermilingua (anteaters), and Tardigrada [=Phyllophaga or Folivora (ground sloths)]. Vermilingua and Tardigrada constitute the clade Pilosa (Delsuc et al., 2002; Gaudin and McDonald, 2008). Scelidotheriinae (middle Miocene-early Holocene) constitute one of the most diverse clades of Tardigrada, restricted to South America. According to the last taxonomic revision, three Quaternary genera and six species are to be considered valid (Miño-Boilini, 2012; Corona et al., 2013).

The first studies on sexual dimorphism of some fossil ground sloths (e.g., Megatheriinae: Eremotherium laurillardi and Mylodontinae: Paramylodon harlani) were carried out by Cartelle and Bohórquez (1982) and McDonald (2006). These authors were able to recognize two morph types on the basis of crania, and concluded that they represent males and females.

Among the valid taxa of Scelidotheriinae, one of their most interesting characteristics are the morphological variations observable at the level of the dorsal crests (parasagittal crests and sagittal crest of the skull) and of the most distal region of the mandible. The goal of this contribution is to describe the two morph types present at skull level in each species. The possibility that this morphology represents sexual dimorphism is discussed.

\section{MATERIAL AND METHODS}

We studied skulls and mandibles of specimens of Quaternary Scelidotheriinae deposited in the collections of various institutions in Argentina and abroad (see institutional abbreviations). The following genera are recognized for the Quaternary period: Scelidotherium Owen, 1839, Valgipes Gervais, 1873, and Catonyx Ameghino, 1891 (see Pujos, 2000; McDonald and Perea, 2002; Cartelle et al., 2009; Miño-Boilini, 2012; Corona et al., 2013).

Most of the skulls and mandibles of the specimens correspond to adult individuals, are in good state of preservation and fairly complete. A total of 47 specimens were studied $(n=10$ Scelidotherium leptocephalum; $\mathrm{n}=6 \mathrm{~S}$. bravardi; $\mathrm{n}=3$ Valgipes bucklandi; $\mathrm{n}=19$ Catonyx tarijensis; $\mathrm{n}=4$ C. chiliensis; $\mathrm{n}=5 \mathrm{C}$. cuvieri). The measures were taken with a digital caliper, with a range of error of 0.5 $\mathrm{mm}$ (Figure 1). The sagittal crest is defined as an evident dorsal hump on the sagittal line of the skull formed by the junction of sagittal crests and with a maximum transverse diameter of $25 \mathrm{~mm}$ (Figures 2-10).

Differences in skull measurements between the two morphotypes (Scelidotherium leptocephalum and Catonyx tarijensis) were assessed by Kruskal-Wallis test. This analysis was not performed in the remaining species because of the low number of available specimens. Differences were considered to be statistically significant at $p<0.05$. Statistical analyses were performed using Infostat Software (Di Rienzo et al., 2012). 


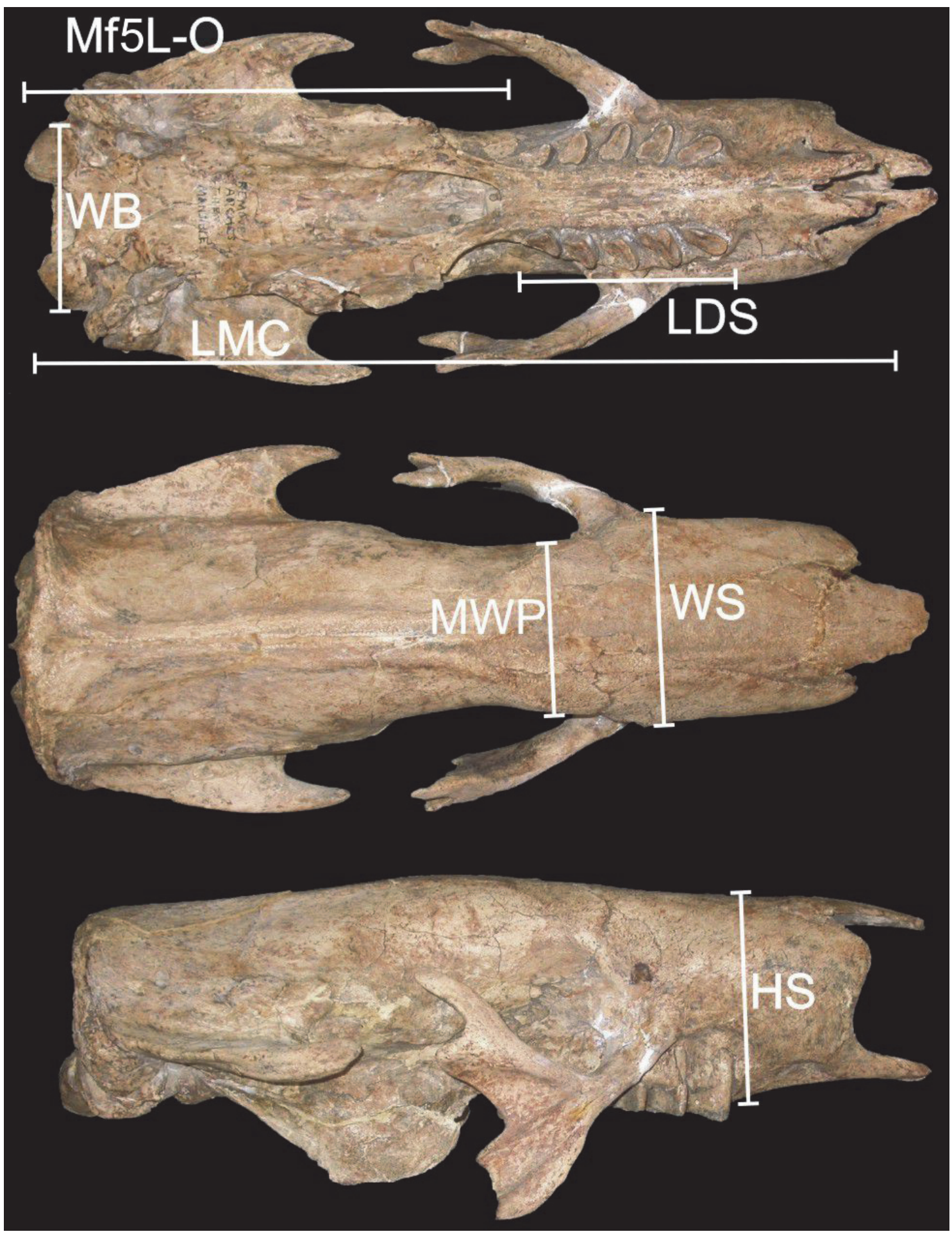

FIGURE 1. Measurements used for comparisons.

Institutional abbreviations. $\mathrm{BM}(\mathrm{NH}) \mathrm{M}$ : British Natural History Museum, London, England; CTESPZ: Paleozoología Corrientes, Facultad de Ciencias Exactas y Naturales y Agrimensura, Universidad Nacional del Nordeste, Corrientes, Argentina; FMNH P: Field Museum of Natural History, Chi- cago, USA; MACN: Sección Paleontología Vertebrados, Museo Argentino de Ciencias Naturales "Bernardino Rivadavia", Buenos Aires, Argentina; MCL: Museu de Ciências Naturais da Pontifícia Universidade Católica de Minas Gerais, Belo Horizonte, Brazil; MD: Museo Municipal "Carlos Dar- 


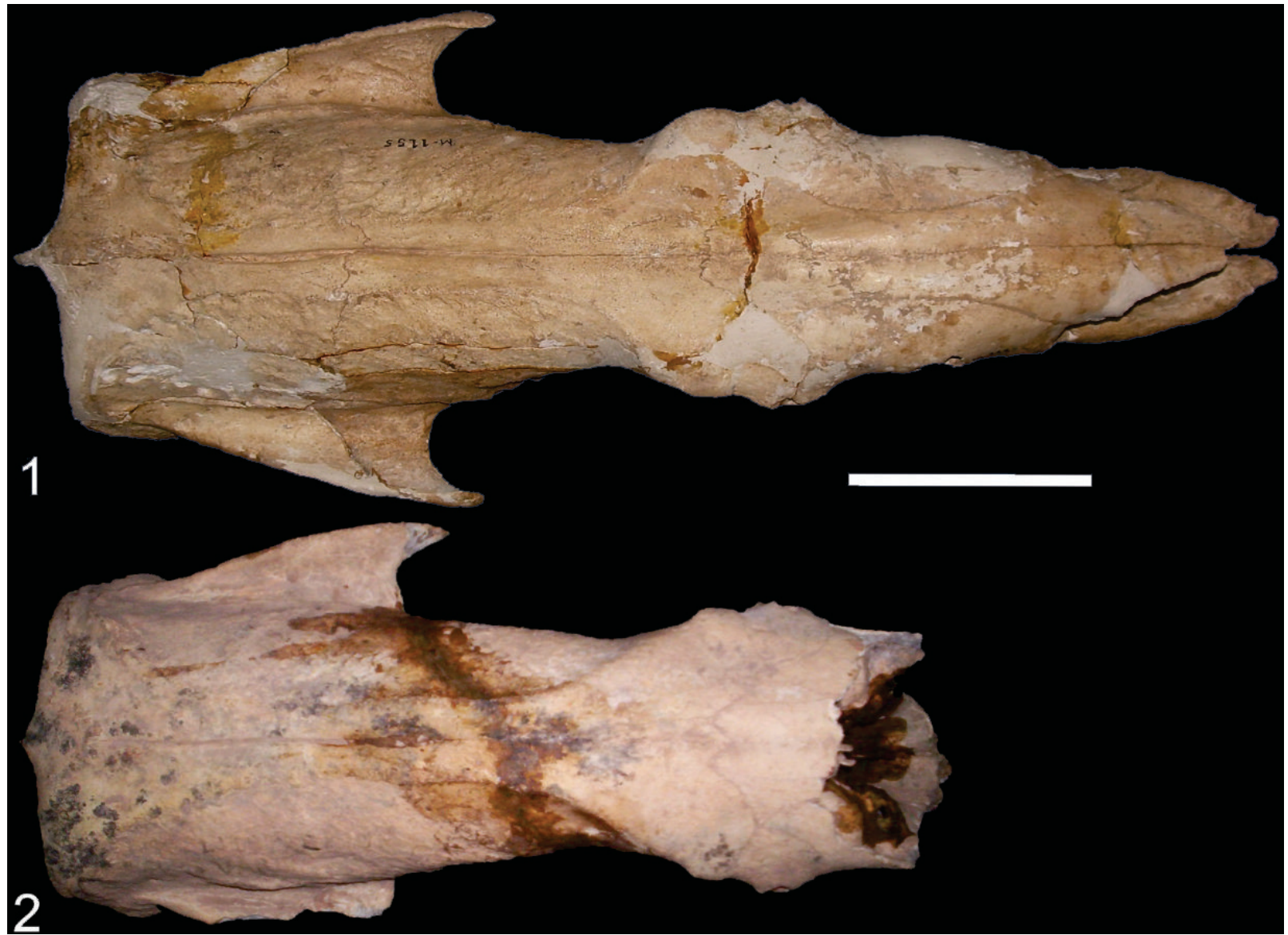

FIGURE 2. Scelidotherium leptocephalum. Skulls in dorsal view. 1, MMP 1155-M; 2, MACN 9625. Scale bar equals 10 $\mathrm{mm}$.

win", Punta Alta, Buenos Aires, Argentina; MFCA: Museo Universitario "Florentino y Carlos Ameghino", Universidad Nacional de Rosario, Santa Fe, Argentina; MLP: División Paleontología Vertebrados, Facultad de Ciencias Naturales y Museo, Universidad Nacional de La Plata, Buenos Aires, Argentina; MHN-UNSL-GEO V: Museo de Historia Natural Universidad Nacional de San Luis, Geología Vertebrados, San Luis, Argentina; MMP: Museo Municipal de Ciencias Naturales de Mar del Plata, "Lorenzo Scaglia", Buenos Aires, Argentina; MNPA: Museo Nacional Paleontológico-Arqueológico, Tarija (ex MUT: Museo Universitario de Tarija), Bolivia; MNHN: Muséum national d'Histoire naturelle, Paris, France; NRM-M: Swedish Museum of Natural History, Stockholm, Sweden, collection Nordenskiöld; PIMUZ A/V, Paleontologisches Institud und Museum der Universität der Zurich, Swiss; ROM: Royal Ontario Museum, Toronto, Canada; SGO-PV: Museo Nacional de Historia Natural, Santiago, Chile; ZMUC: Zoologisk
Museum Universitat Copenhagen, Copenhagen, Denmark.

Anatomical abbreviations. Mf/mf: upper/lower molariform tooth.

Measurement abbreviations. WB: width bicondylar; LMC: length maxillar-condylar; LDS: length of dental series; MWP: minimum width postorbital; OMf5L: distance between the occipital condyles and the posterior edge of molariform 5; WS: width of snout; HS: height of snout.

\section{SYSTEMATIC PALEONTOLOGY}

(Tables 1 and 2)

Superorder XENARTHRA Cope, 1889

Order TARDIGRADA Latham and Davies in

Forster, 1795

Family MYLODONTIDAE Gill, 1872

Subfamily SCELIDOTHERIINAE Ameghino, 1904

Genus Scelidotherium Owen, 1839 


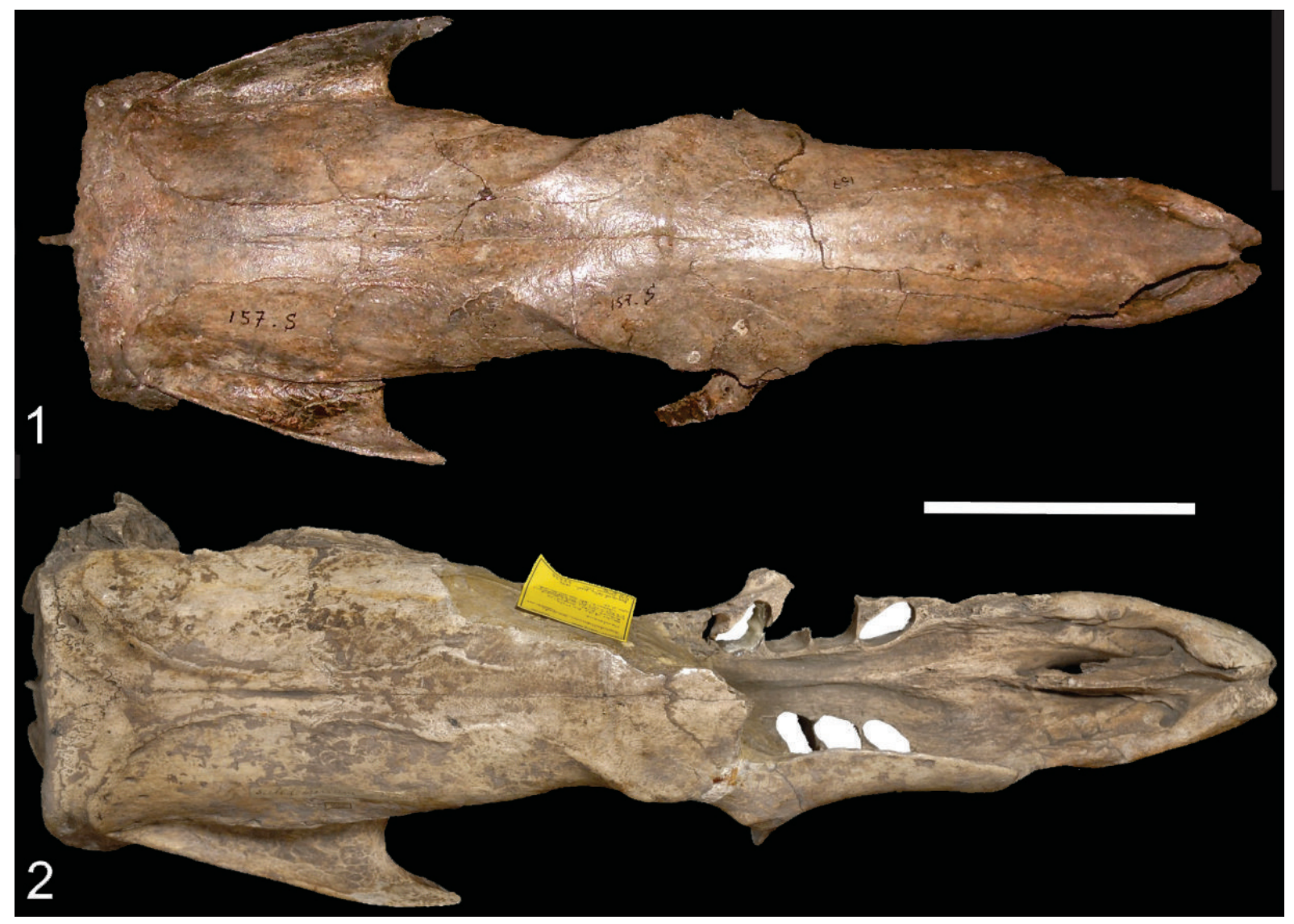

FIGURE 3. Scelidotherium bravardi. Skulls in dorsal view. 1, MMP 157-S; 2, holotype BM(NH)M 37626. Scale bar equals $10 \mathrm{~mm}$.

\section{Scelidotherium leptocephalum Owen, 1839}

(Figure 2.1-2)

Referred material. FMNH P 14274, skull, mandible, right scapula, left humerus, right and left ulnas, left and right radius, some bones from the autopod; FMNH P 14267, skull; MACN 9625, partial skull; MACN 13880, partial skull; MACN 13883, skull; MLP 3-409, partial skull, toothless; MMP 1155-M, skull and mandible; MLP 3-402, skull; MLP 3-408, skull and right hemimandible; MFCA 757, skull.

Description. In dorsal view, the parasagittal crests start in the nuchal crest and end at the postorbital process of the frontal bone, as in all Quaternary Scelidotheriinae, but no sagittal crest is observed. This morphology allows the identification of two variants. In some specimens (FMNH P 14274, FMNH P 14267, MMP 1155, MLP 3-402, MFCA 757 , and MLP 3-408), the parasagittal crests are parallel along all their extension (at the level of the parietal and frontal) (Figure 2.1). In other specimens (MACN 9625, MACN 13880, MACN 13883, and MLP 3-409), the parasagittal crests are parallel to each other at the level of the parietal, but have a "horseshoe" shape at the level of the fronto-parietal suture, delimiting a rhomboidal morphology; in their most anterior portion, parasagittal crests become parallel again (Figure 2.2).

\section{Scelidotherium bravardi Lydekker, 1886}

(Figure 3.1-2)

Referred material. BM(NH)M 37626, skull almost complete; MMP 9-S, partial skull; MMP 31-S, skull and partial mandible; MMP 128-S, toothless skull; MMP 458-S, skull, mandible, left femur, right radius, patella; MMP 157-S, skull and mandible.

Description. The morphology observed is very similar to that of Scelidotherium leptocephalum, without the development of a sagittal crest. In some specimens, the parasagittal crests are parallel in all their extension (MMP 9-S, MMP 31-S, MMP 128-S, and MMP 157-S) (Figure 3.1), while in others they show a rhomboidal outline at the level of the fronto-parietal suture [BM(NH)M 37626 and MMP 158-S] (Figure 3.2). 


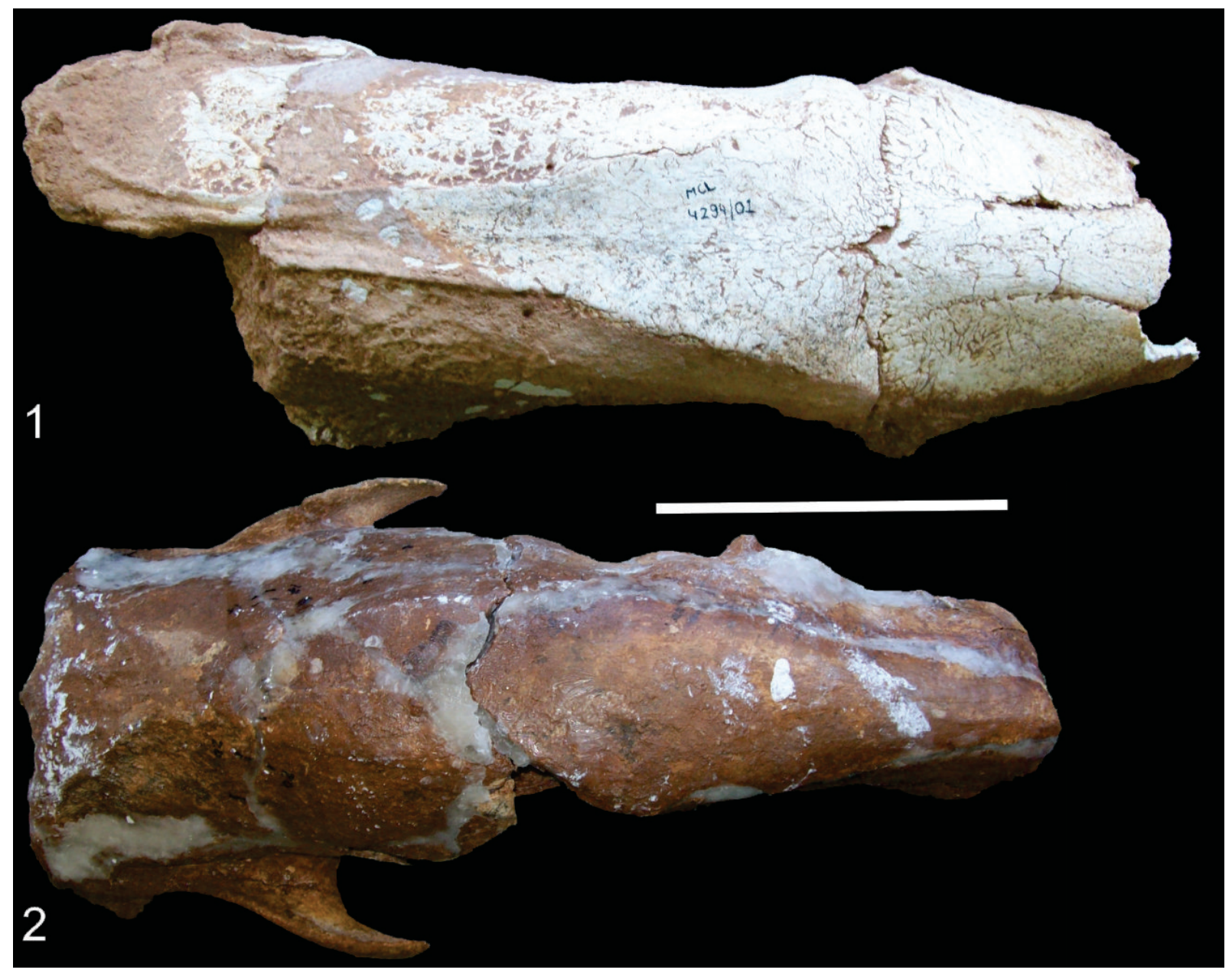

FIGURE 4. Valgipes bucklandi. Skulls in dorsal view. 1, MCL 4294; 2, MCL 4293. Scale bar equals $10 \mathrm{~mm}$.

Genus Valgipes Gervais, 1873

Valgipes bucklandi (Lund, 1839)

(Figure 4.1-2)

Referred material. MCL 4262, skull almost complete, hemimandible with a portion of the symphysis, with the mf1-2 and dermal ossicles; MCL 4264, partial skull, partial right hemimandible, left and right astragali, right tibia and fibula; MCL 4293, partial skull, partial right hemimandible that preserves only the $\mathrm{mf} 3$, several vertebrae, almost complete hand, right femur, right tibia and fibula, right and left astragali.

Description. In dorsal view, the parasagittal crests start at the nuchal crest and end at the level of the postorbital process of the frontal. In some specimens (MCL 4294 and MCL 4262), a little behind the fronto-parietal suture, the parasagittal crests differ in the form of "wedge" in the direction of the postorbital processes, with the presence of a sagittal crest on the middle line of the parietal (Figure 4.1). In contrast, specimen MCL 4393 does not have the sagittal crest, and its parasagittal crests have the same morphology (Figure 4.2).

Genus Catonyx Ameghino, 1891

Catonyx tarijensis (Gervais and Ameghino, 1880)

(Figures 5.1-2, 6.1-2)

Referred material. CTES-PZ 7151, partial skull; CTES-PZ 1690, posterior portion of the skull; FCS 96.I15/1/2, partial skull; FMNH P 14238, skull, mandible, left scapula, left and right humerus, ulna and radius, left femur; FMNH P 13733, partial skull; MACN 1138, posterior portion of the skull; MNPA-V 005769, skull and mandible; MNPA-V 005750 (former MUT 32), skull and mandible; MNPA-V 005766 (former MUT 298), skull and partial mandible; MNHN TAR 1260, holotype of Scelidodon tarijensis, partial skull and mandible associated; MNPA-V s/n (former MUT 166), skull and mandible associated; MNPA-V s/n (former MUT 446), partial mandible, with molariforms; MNPA-V s/n (former MUT 007), partial mandible, with molariforms; NRM-M 4444, skull and mandible; FMNH P 14243, 


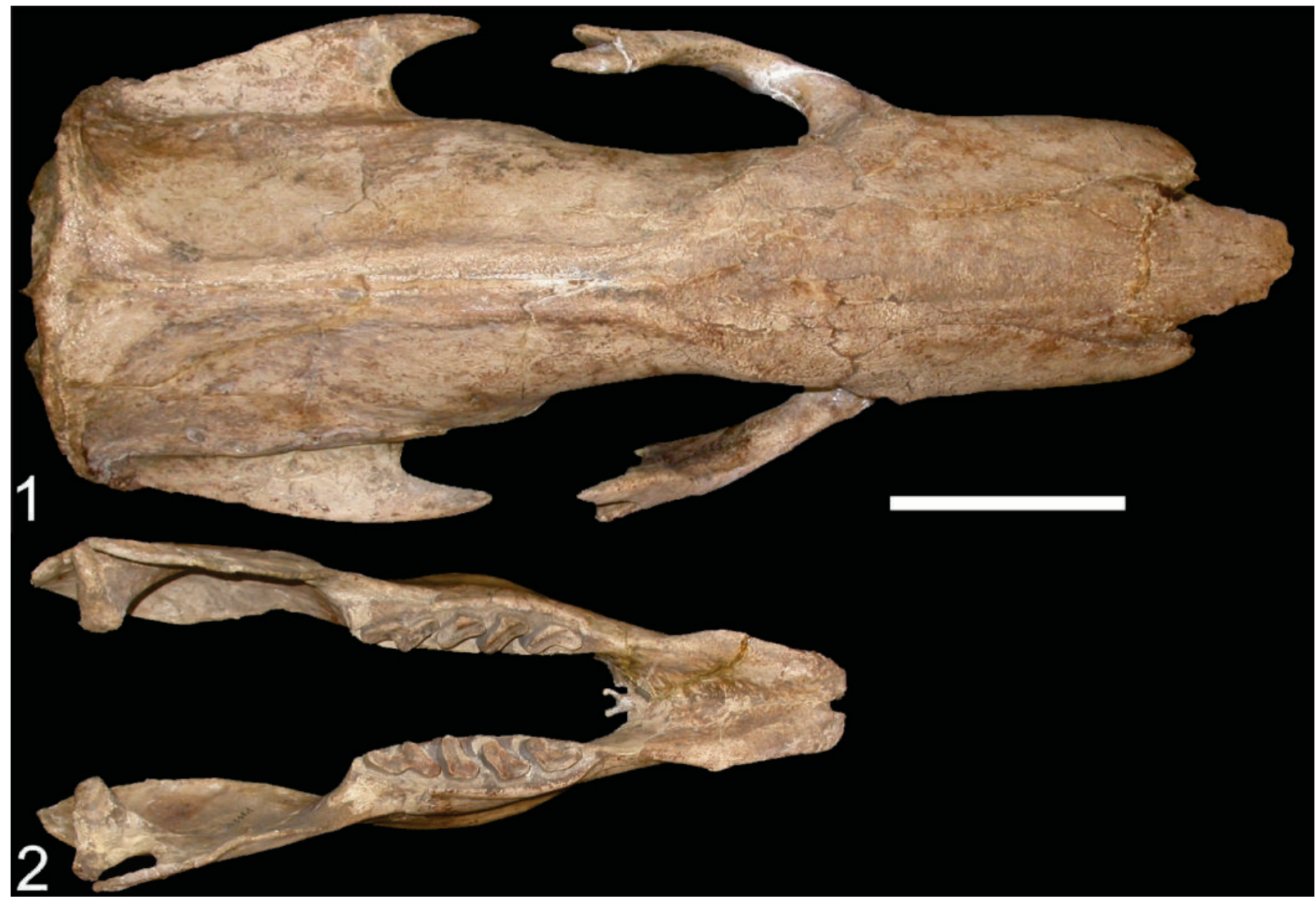

FIGURE 5. Catonyx tarijensis. Skull and mandible in dorsal view. 1 and 2 FMNH P 14243. Scale bar equals $10 \mathrm{~mm}$.

skull and mandible, portions of the postcranial; MD-97-23, partial skull; MMP 3989, posterior portion of the skull; MMP 1267, complete skull, mandible nearly complete, humerus, ulna, radius, all in good state of preservation; PIMUZ A/V 0512, partial skull.

Description. The parasagittal crests originate in the nuchal crest and end at the level of the postorbital process of the frontals. In some specimens (FMNH P 14243, MNHN TAR 1260, MNPA-V 005750, MNPA 005766, MNPA-V 005769, MUT 166, MACN 1138, MMP 3989, NRM-M 4444, and CTES-PZ 7151), the sagittal crest has a high degree of development and is straight along all its extension, and diverges only in the most anterior part of the frontals (Figure 5.1). In other specimens (FMNH P 13733, MD 97-23, PIMUZ A/V 0512, MMP 1267, and CTES-PZ 1690), the sagittal crest starts diverging at the level of the fronto-parietal suture and ends at the post-orbital narrowing, acquiring an "hourglass" shape. Finally, only two specimens (FMNH P 14238 and FCS 96.I15/1/2) show total absence of dorsal crests (Figure 6.1).
Catonyx chiliensis (Lydekker, 1886)

(Figure 7.1-2)

Referred material. BM(NH)M 2819, partial skull; SGO-PV 188, posterior portion of the skull; ROM 2089, partial skull, ROM 4572, partial skull; MHINUNSL-GEO V 199, partial skull in a good state of preservation, only preserving the right Mf1.

Description. In this taxon, the parasagittal crests start in the nuchal crest and end at the level of the postorbital process of the frontal, as in all Quaternary Scelidotheriinae. In some specimens (RON 4572 and $B M(\mathrm{NH}) \mathrm{M} 2819$ ), the sagittal crest is slightly developed at the level of the parietals, and the parasagittal crests differ at the level of the fronto-parietal suture (Figure 7.1). In contrast, in other specimens (ROM 2089, SGO-PV 188, MHINUNSL-GEO $\vee 199$ ), the parasagittal crests fail to develop into a sagittal crest (Figure 7.2).

\section{Catonyx cuvieri (Lund, 1839)}

(Figure 8.1-2)

Referred material. MCL 4265, partial skull, right humerus, ulnas and left and right radii, partial right scapula, astragali and right and left calcanei, several vertebrae; MCL 4259, partial skull; MCL 


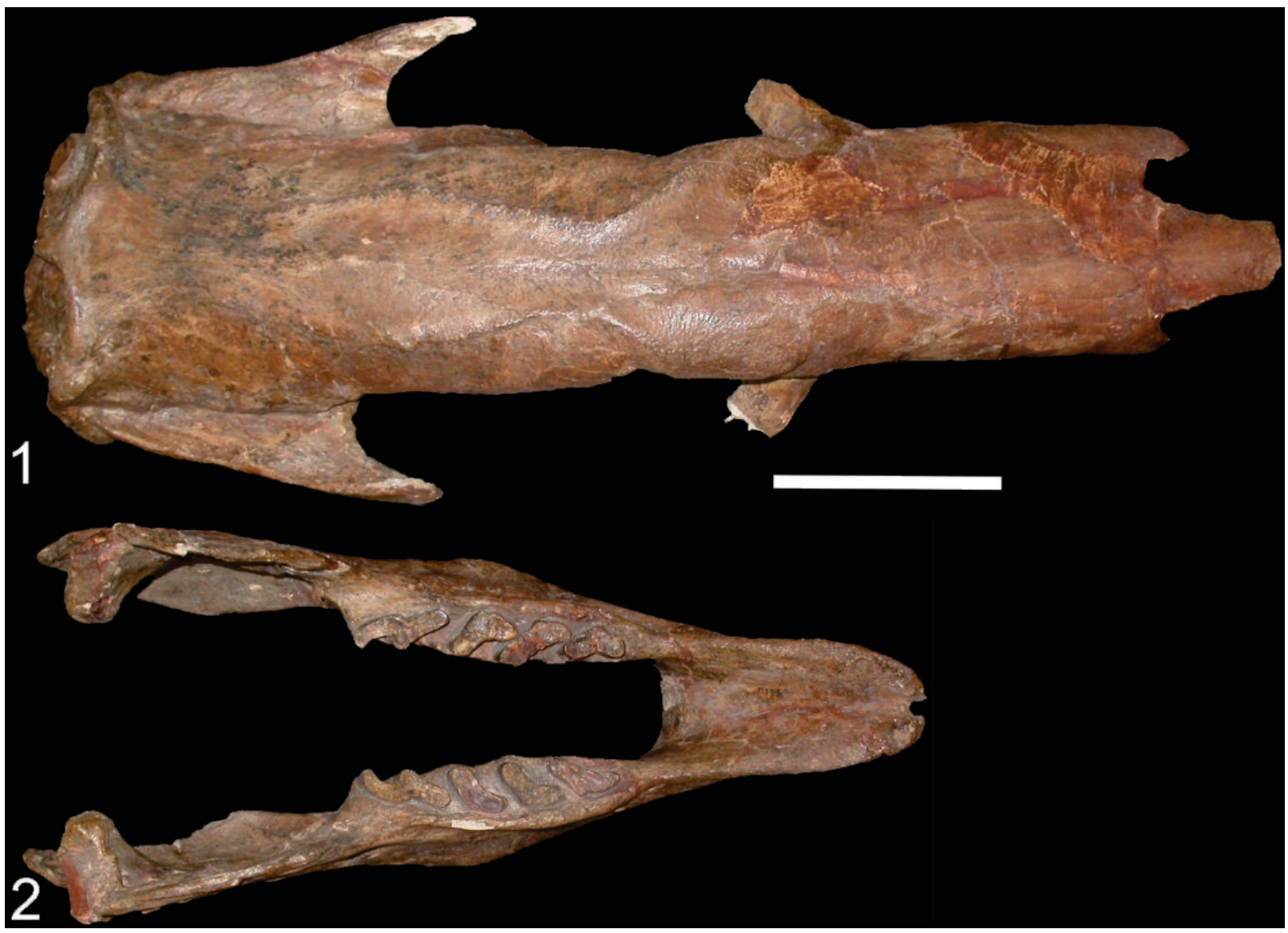

FIGURE 6. Catonyx tarijensis. Skull and mandible in dorsal view. 1 and 2 FMNH P 14238. Scale bar equals $10 \mathrm{~mm}$.

22682, partial skull; MCL 22683, partial skull; ZMUC 1668, partial skull.

Description. Like in the other taxa discussed above, the parasagittal crests start in the nuchal crest and end at the level of the postorbital process of the frontal (Figure 8.1). Some specimens (MCL 4265, MCL 4259) show a straight sagittal crest at the level of the sagittal line in parietals and frontals, whereas others (MCL 22682, MCL 22683, and ZMUC 1668) do not present the sagittal crest (Figure 8.2).

\section{DISCUSSION AND CONCLUSIONS}

Among Eutheria, Xenarthra has been interpreted as a clade with a low degree of sexual dimorphism (see Lara-Ruiz and Chiarello, 2005; Squarcia et al., 2009). This is in part corroborated by the fact that the only modern contributions to extant taxa are limited to the Tardigrada Bradypodidae Bradypus torquatus Illiger, 1811 (Lara-Ruiz and Chiarello, 2005) and the Cingulata Dasypodidae Chaetophractus villosus Desmarest, 1804 (Squarcia et al., 2009). This situation clearly con- trasts with that observed in both fossil and living species belonging to other orders, such as Proboscidea, in which a clear sexual dimorphism has been established in Mammut americanum Kerr, 1792 and Loxodonta Anonymous, 1827 (Smith and Fisher, 2013).

Concerning fossil Xenarthra, sexual dimorphism cases reported only correspond to the Tardigrada Mylodontinae and Megatheriinae (Pujos et al., 2012). A pioneer work on this subject is that of Cartelle and Bohórquez (1982), who mentioned a series of characters that may indicate sexual dimorphism in specimens of Eremotherium laurillardi Lund, 1842, from Gruta das Onca, Municipio de Jacobina, Bahia State (Brazil) in the late Pleistocene-Holocene. The characters mentioned are present at the level of the skull, more precisely on the dorsal crests (sagittal crest, supraorbital crests). Cartelle and Bohórquez (1982) suggested that the sagittal crest is more developed in males and less developed in females and that this could have taxonomic implications. They thus suggested 


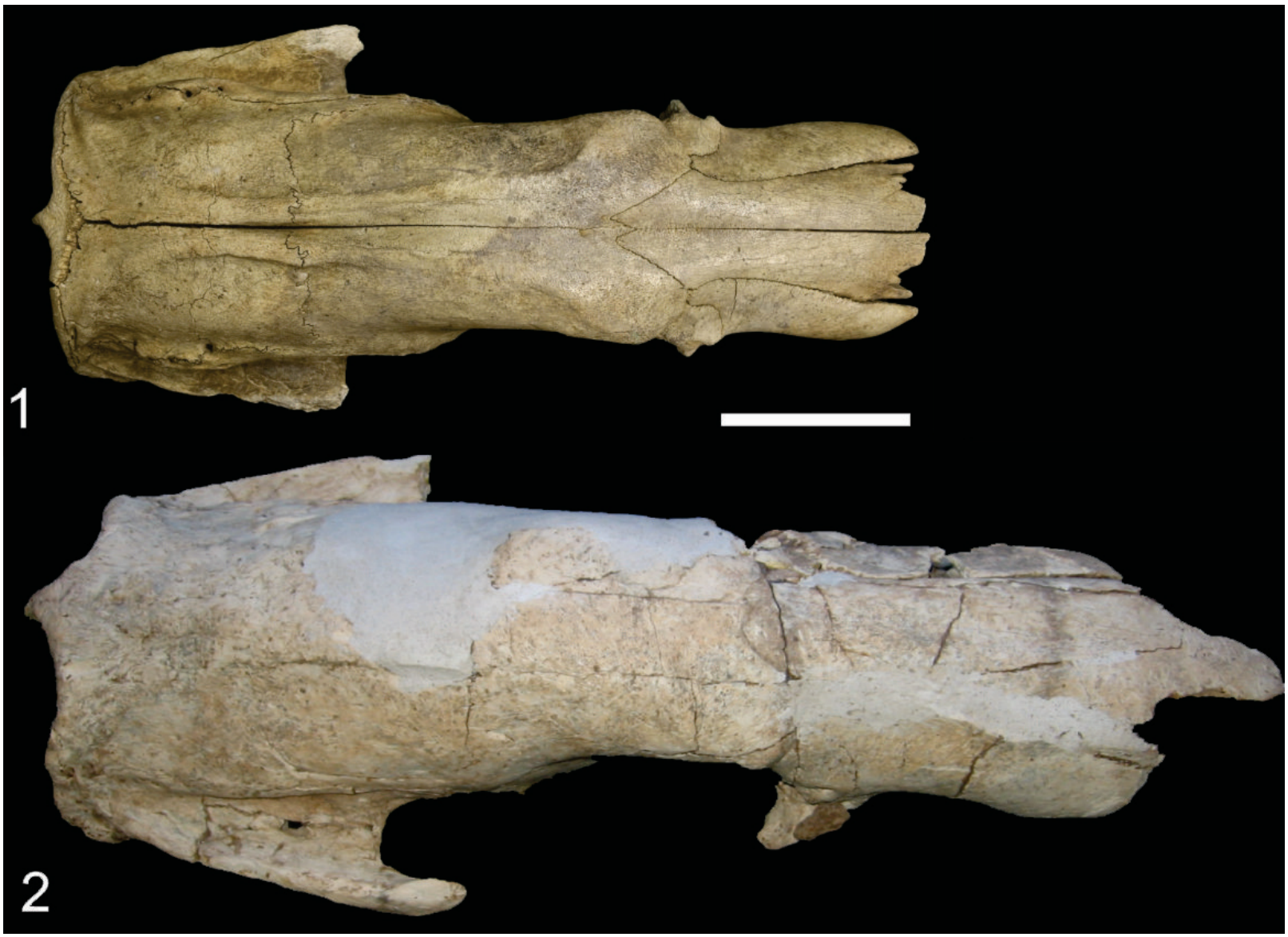

FIGURE 7. Catonyx chiliensis. Skulls in dorsal view. 1, BM(NH)M 2819; 2, MHIN-UNSL-GEO V 199. Scale bar equals $10 \mathrm{~mm}$.

possible synonymy among species of Eremotherium.

In a subsequent contribution, De luliis and Cartelle (1999) indicated that specimens of Eremotherium eomigrans De luliis and Cartelle, 1999, from the late Pliocene - early Pleistocene of Florida (USA), show the same distribution of characters as in Eremotherium laurillardi, suggesting the presence of sexual dimorphism in this taxon. In summary, and in agreement with Cartelle and Bohórquez (1982) and De luliis and Cartelle (1999), E. laurillardi and E. eomigrans show sexual dimorphism within Megatheriinae, and the characters are mainly at the level of the skull and mandible. In this context, it is important to remark that Cartelle and Bohórquez (1982) and De luliis and Cartelle (1999) expressed no hypotheses concerning possible social structure in this taxon.

More recently, McDonald (2006) conducted a study on the variation of the skull of Mylodontinae of the Pleistocene of Rancho La Brea (USA), where he analyzed two cranial morphologies tradi- tionally interpreted as belonging to two subspecies, Paramylodon harlani harlani (Owen, 1840) and Paramylodon harlani tenuiceps (Stock, 1917). His results show that the specimens can be separated into two groups: one with relatively more robust skulls (Paramylodon harlani harlani) and the other with more slender skulls (Paramylodon harlani tenuiceps). McDonald (2006) also observed some variation in the occlusal surface of the caniniform (e.g., in lateral view, some have an oblique occlusal surface whereas others have a perpendicular one). In summary, McDonald (2006) observed two skull morphologies, a "robust" and a "slender" one, which could, in fact, correspond to males and females of the same species. Based on the ungulate model, McDonald (2006) suggested that Paramylodon would have solitary to semi-solitary habits or would have formed small, single-sex social groups during much of the year. On the other hand, and following the carnivore model, the medium-high sexual dimorphism observed in 


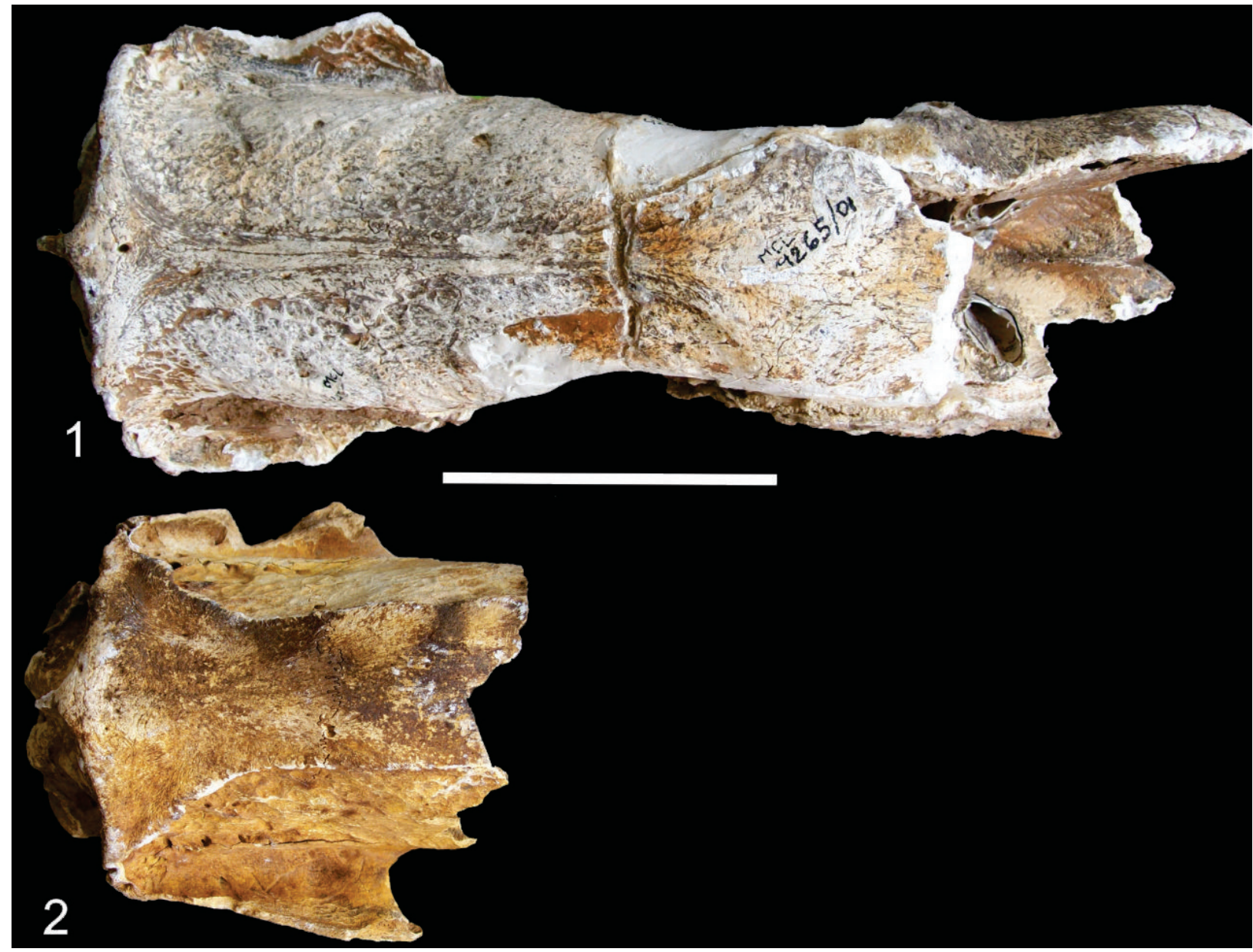

FIGURE 8. Catonyx cuvieri. Skulls in dorsal view. 1, MCL 4265; 2, MCL 22683. Scale bar equals 10 mm.

Paramylodon could indicate a polygamous lifestyle.

Brandoni et al. (2010), in a revision of Mylodon darwini Owen, 1839, concluded that it was not possible to observe sexual dimorphism in this species.

Lastly, Czerwonogara and Fariña (2013) revised the two recognized species of Lestodon Gervais, 1855 (Lestodon armatus Gervais, 1855 and Lestodon australis Kraglievich, 1934), including an estimation of body mass. Their results suggested that no dimorphism is present in this genus, and that there is one valid species, $L$. armatus. These authors suggested that in large fossil ground sloths, such as Eremotherium laurillardi, it is possible to observe an evident sexual dimorphism, as in large mammals. However, one important point, as highlighted by McDonald (2006) in Paramylodon and by Czerwonogara and Fariña (2013) in Lestodon, is that in their samples skulls were not associated with the pelvis, suggesting that their conclusions regarding sexual dimorphism are open to revision.

In this scenario, it is also important to note that Prothero and Raymond (2008) suggested that size sexual dimorphism in sloths is not as widespread a character as once believed.

In our study we were able to recognize two morphological variants in each species analyzed (Figures 9, 10). In Valgipes bucklandi, Catonyx tarijensis, C. chilensis, and C. cuvieri, the differences observed included the presence and absence of a sagittal crest. On the other hand, C. tarijensis is the only Scelidotheriinae that also shows two morphological variants at mandible level. One of these variants presents an edge at the level of the anterior portion of the mandibular ramus that is similar in occlusal view to a "duck's bill" (MNPA 005769 and FMNH P 14243) (Figures 5.2, 10.2), whereas the other lacks this edge (MNPA 005750, FMNH P 14248 and MRN-M 4444) (Figures 6.2, 10.4). These two morphologies seem to be related to the presence and absence of a sagittal crest, respec- 

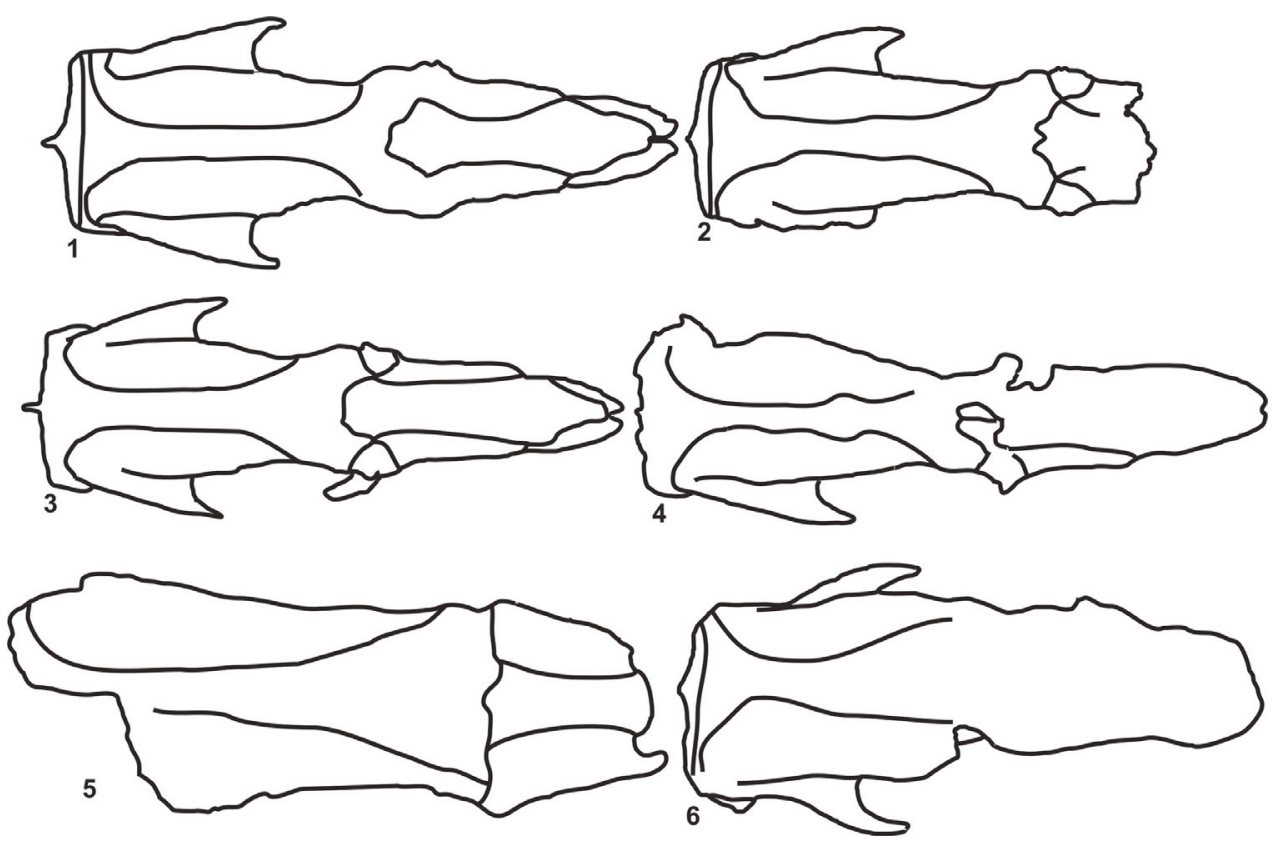

FIGURE 9. Skull outlines in dorsal view. 1 and 2, Scelidotherium leptocephalum (MMP 1155-M, MACN 9625); 3 and 4, Scelidotherium bravardi (MMP 157-S, BM(NH)M 37626); 5 and 6, Valgipes bucklandi (MCL 4294, 4393).
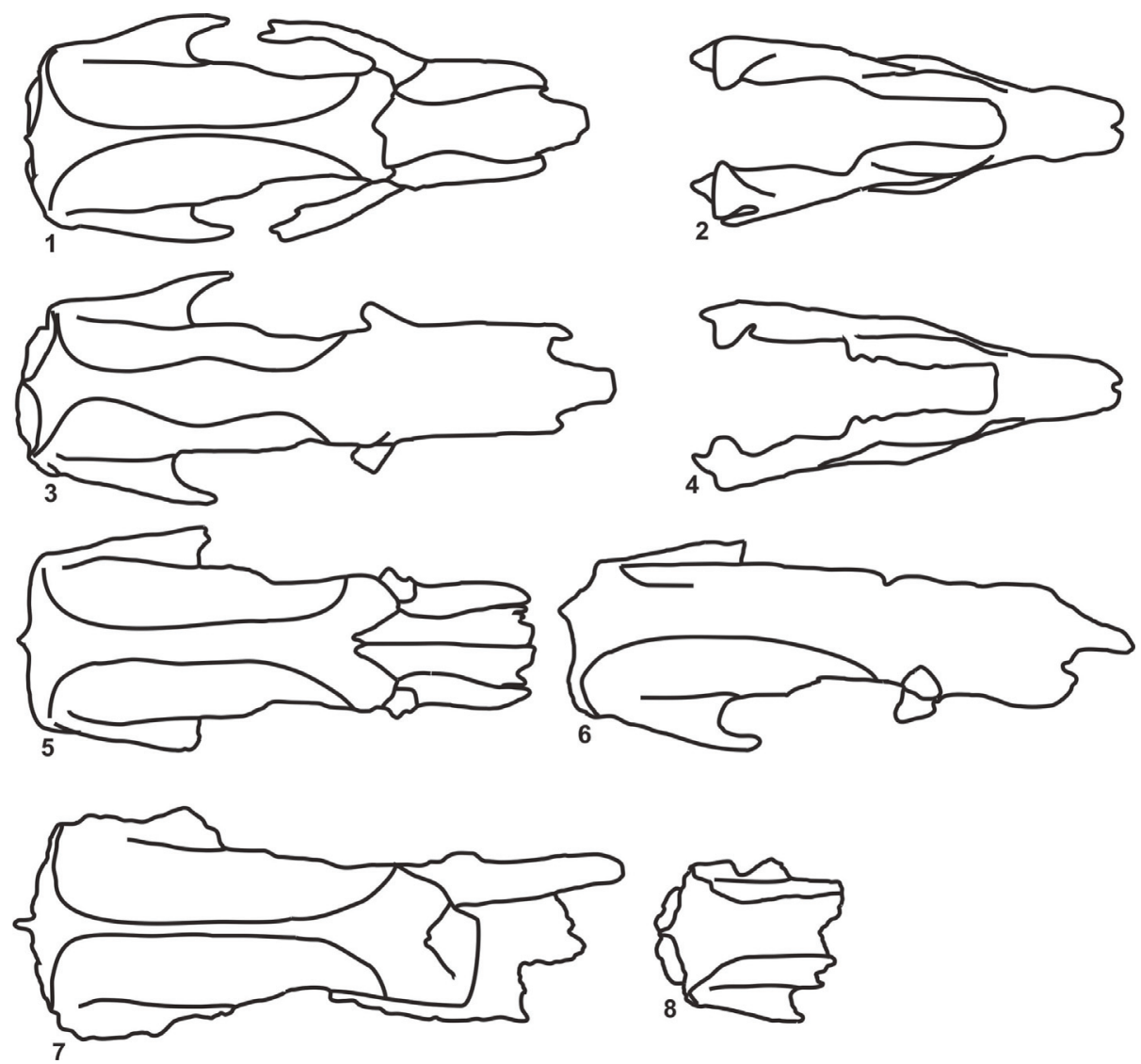

FIGURE 10. Skull and mandible outlines in dorsal view. 1 and 2, Catonyx tarijensis (FMNH P 14243); 3 and 4, Catonyx tarijensis (FMNH P 14238); 5 and 6, Catonyx chiliensis (BM(NH)M 2819 Type, MHIN-UNSL-GEO V 199); 7 and 8, Catonyx cuvieri (MCL 4265, MCL 22683). 
TABLE 1. Comparative measurements (in mm) of skulls. *Approximate.

\begin{tabular}{|c|c|c|c|c|c|c|c|}
\hline Taxa & LMC & LDS & MWP & WS & HS & OMf5L & WB \\
\hline S. leptocephalum (FMNH P 14274) & 520 & 110 & 109 & 100 & 125 & 295 & 117 \\
\hline S. leptocephalum (FMNH P 14267) & 400 & 90 & 100 & 90 & 111 & 225 & 111 \\
\hline S. leptocephalum (MLP 3-409) & 415 & 85 & 95 & 85 & 105 & 230 & 100 \\
\hline S. leptocephalum (MLP 3-408) & 400 & 85 & 90 & 75 & 100 & 200 & 82 \\
\hline S. leptocephalum (MLP 3-402) & 470 & 105 & 90 & 95 & 105 & 250 & 100 \\
\hline S. leptocephalum (MACN 13880) & 550 & 110 & 100 & 100 & 125 & 290 & 110 \\
\hline S. leptocephalum (MACN 13883) & 515 & 105 & 90 & 90 & 115 & 275 & 100 \\
\hline S. leptocephalum (MACN 9625) & --- & 110 & 105 & 97 & --- & 270 & 100 \\
\hline S. leptocephalum (MMP 1155-M) & 520 & 110 & 120 & 100 & 145 & 260 & 115 \\
\hline S. leptocephalum (MFCA 757) & 510 & 111 & 94 & 93 & 105 & 254 & 98 \\
\hline S. bravardi (MMP 9-S) & 410 & 90 & 75 & 75 & 113 & 230 & 105 \\
\hline S. bravardi (MMP 31-S) & 500 & 109 & 95 & 95 & 135 & 295 & 112 \\
\hline S. bravardi (MMP 128-S) & 405 & 100 & 85 & 85 & 116 & 242 & 120 \\
\hline S. bravardi (MMP 458-S) & 385 & 88 & 80 & 81 & 110 & 213 & 77 \\
\hline S. bravardi (MMP 157-S) & 560 & 113 & 96 & 80 & 117 & 278 & 116 \\
\hline V. bucklandi (MCL 4262) & 365 & 110 & 87 & 70 & 100 & 190 & 95 \\
\hline V. bucklandi (MCL 4293) & 405 & 110 & 90 & 77 & 110 & 230 & 100 \\
\hline C. tarijensis (CTES-PZ 7151) & 540 & 120 & 97 & 123 & 113 & 300 & 120 \\
\hline C. tarijensis (MMP 1267) & 540 & 135 & 90 & 110 & 140 & 283 & 125 \\
\hline C. tarijensis (FMNH P 14243) & 500 & 120 & 90 & 120 & 125 & 285 & 123 \\
\hline C. tarijensis (FMNH P 14238) & 550 & 135 & 100 & 105 & 127 & 285 & 123 \\
\hline C. tarijensis (FMNH P13733) & 490 & 130 & 97 & 110 & 120 & 290 & 120 \\
\hline C. tarijensis (MD-97-23) & 465 & 112 & 90 & 100 & 117 & 285 & 112 \\
\hline C. tarijensis (MNPA 005750) & 482 & 130 & 97 & 110 & 120 & 290 & 120 \\
\hline C. tarijensis (MNPA 005766) & *466 & 126 & 110 & 106 & -- & *273 & --- \\
\hline C. tarijensis (PIMUZ A/V 0512) & 504 & 131 & 110 & 97 & 136 & 303 & 116 \\
\hline C. chiliensis (MHIN-UNSL GEO V199) & 520 & *120 & 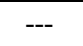 & $* 110$ & 110 & *300 & 110 \\
\hline C. chiliensis (ROM 2089) & 450 & ${ }^{\star} 90$ & --- & --- & --- & 250 & 105 \\
\hline C. cuvieri (MCL 4265) & *370 & 100 & *80 & *85 & --- & 220 & 120 \\
\hline C. cuvieri (MCL 4259) & 350 & 100 & *85 & --- & --- & 210 & --- \\
\hline
\end{tabular}

tively. It is important to highlight that two species of Quaternary Scelidotheriinae (Scelidotherium leptocephalum and S. bravardi) do not have a sagittal crest. In these taxa, the differences involve the morphology of the parasagittal crests. In some specimens, the parasagittal crests are parallel for their entire extension, while in others they show a rhomboidal outline at the level of the fronto-parietal suture.

No significant differences between the two morphtypes of Scelidotherium leptocephalum and Catonyx tarijensis of the dorsal crests of the skull were observed across all variables (Kruskal Wallis test, $p>0.05, n=10$ S. leptocephalum; $n=9$ C. tarijensis) (Table 3).

Following Cartelle and Bohórquez (1982), we suggest that the specimens with sagittal crest likely represent males, while those lacking sagittal crests represent females. In the case of Scelidotherium leptocephalum and $S$. bravardi, the two recognized morphs do not involve the presence/absence of sagittal crest but different morphologies of the parasagittal crests. Finally, it is important to remark that any hypothesis about sexual dimorphism in fossil ground sloths must be taken with care. This is mainly due to the fact that living sloths (Bradypus and Choloepus) represent a very different ecological model (i.e., a completely arboreal lifestyle) to these extinct species.

\section{ACKNOWLEDGEMENTS}

We are grateful to A.A. Carlini and G.J. Sclillato-Yané for their support and dedication during the course of the Doctoral Thesis of one of the authors (ARMB). We also thank A. Kramarz, L. Cruz, A. Dondas, T. Manera de Bianco, R. Tomassini, C. Cartelle, F. Paredes-Rios, J. Chiesa, and N. Lucero for giving us the access to the collections under their care. D. Rubilar-Rogers, M. Andersen, A. Currant, K. Seymour, L. Werdelin, and H.G. McDonald are also thanked for sending photographs. The comments of the editor J. Louys and 
TABLE 2. Acronyms and list of specimens of Scelidotherium, Valgipes, and Catonyx mentioned in the text.

\begin{tabular}{|c|c|c|}
\hline Material & \multirow{11}{*}{\begin{tabular}{|l|}
\multicolumn{1}{|c|}{ Taxa } \\
S. \\
leptocephalum
\end{tabular}} & Stratigraphic and geographic procedence \\
\hline FMNH P 14274 & & Pleistocene, Río Quequén, Buenos Aires, Argentina. \\
\hline FMNH P 14267 & & Pleistocene, Buenos Aires, Argentina. \\
\hline MACN 9625 & & "Upper Pampean", Laguna Vital, Chascomús, Buenos Aires, Argentina. \\
\hline MACN 13880 & & "Pampean", Necochea, Buenos Aires, Argentina. \\
\hline MACN 13883 & & "Pampean", Necochea, Buenos Aires, Argentina. \\
\hline MLP 3-409 & & "Upper Pampean", Argentina. \\
\hline MLP 3-402 & & "Pampean", Buenos Aires, Argentina. \\
\hline MLP 3-408 & & "Upper Pampean", Buenos Aires, Argentina. \\
\hline MMP 1155 & & Lobería Formation, Lujanian, Mar del Plata, Buenos Aires, Argentina. \\
\hline MFCA 757 & & "Pampean" Formation, right bank of the Paraná River, Alvear, Santa Fe, Argentina. \\
\hline BM(NH)M 37626 (Type) & \multirow[t]{6}{*}{ S. bravardi } & Ensenada Formation, "Toscas" del Río de La Plata, Buenos Aires, Argentina. \\
\hline MMP 9-S & & $\begin{array}{l}\text { Ensenadan, NE of the city of Mar del Plata, in front of Santa Elena beach, General } \\
\text { Pueyrredón, Buenos Aires, Argentina. }\end{array}$ \\
\hline MMP 31-S & & $\begin{array}{l}\text { Ensenadan?, coastal cliffs in front of Parque Camet, Mar del Plata, Buenos Aires, } \\
\text { Argentina. }\end{array}$ \\
\hline MMP 128-S & & $\begin{array}{l}\text { Miramar Formation, base of the cliffs in front the dairy farm of the field of Cobo Mar } \\
\text { del Plata, Buenos Aires, Argentina. }\end{array}$ \\
\hline MMP 458-S & & $\begin{array}{l}\text { Ensenadan, coastal cliff, } 800 \mathrm{~m} \text { to the NNE of the pipe drain of the city of Mar del } \\
\text { Plata, Buenos Aires, Argentina. }\end{array}$ \\
\hline MMP 157-S & & Ensenadan?, Estrada beach, Mar del Plata, Buenos Aires, Argentina. \\
\hline MCL 4262 & \multirow[t]{3}{*}{ V. bucklandi } & Late Pleistocene, Serra do Ramallo, North of Minas Gerais, Brazil. \\
\hline MCL 4293 & & Pleistocene, Gruta Volta da Serra 3, São José das Missões, Minas Gerais, Brazil. \\
\hline MCL 4264 & & Late Pleistocene, Iraquara, Brazil. \\
\hline CTES-PZ 7151 & \multirow[t]{14}{*}{ C. tarijensis } & Late Pleistocene, Lavalle, Corrientes, Argentina. \\
\hline CTES-PZ 1690 & & Yupoí/Toropí Formation, Late Pleistocene, arroyo Toropí, Corrientes, Argentina. \\
\hline FCS $96.115 / 1 / 2$ & & Pleistocene, Olavarría, Buenos Aires, Argentina. \\
\hline FMNH P 14243 & & Pleistocene, Padcaya, Bolivia. \\
\hline FMNH P 14238 & & Pleistocene, Tarija, Bolivia. \\
\hline FMNH P 13733 & & Pleistocene, Tarija, Bolivia. \\
\hline MNH TAR 1260 (Type) & & Pleistocene, Tarija, Bolivia. \\
\hline MNPA-V 005769 & & Pleistocene, Tarija, Bolivia. \\
\hline MNPA-V 005750 & & Pleistocene, Tarija, Bolivia. \\
\hline MNPA-V 005766 & & Pleistocene, Tarija, Bolivia. \\
\hline MNPA-V s/n (MUT 166) & & Pleistocene, Tarija, Bolivia. \\
\hline MNPA-V s/n (MUT 446) & & Pleistocene, Tarija, Bolivia. \\
\hline MNPA-V s/n (MUT 007) & & Pleistocene, Tarija, Bolivia. \\
\hline NRM-N 4444 & & Pleistocene, Tarija, Bolivia. \\
\hline MACN 1138 & & Pleistocene, Tarija, Bolivia. \\
\hline MMP 3989 & & Ensenadan, Mar del Plata, Buenos Aires, Argentina. \\
\hline MMP 1267 & & Bonaerian, north of Mar del Plata, Buenos Aires, Argentina. \\
\hline MD-97-23 & & Bonaerian-Lujanian, Playa del Barco, Pehuen có, Buenos Aires, Argentina. \\
\hline PIMUZ A/V 0512 & & Pleistocene, arroyo Maciel, Buenos Aires, Argentina. \\
\hline
\end{tabular}


TABLE 2 (continued).

\begin{tabular}{|c|c|c|}
\hline Material & Taxa & Stratigraphic and geographic procedence \\
\hline $\mathrm{BM}(\mathrm{NH}) \mathrm{M} 2819$ & \multirow[t]{5}{*}{ C. chiliensis } & Late Pleistocene, Tamarugal, Tarapacá district, Chile. \\
\hline SGO-PV 188 & & Late Pleistocene, close to the Desaguadero River, Ulloma, La Paz, Bolivia. \\
\hline ROM 2089 & & Late Pleistocene, Guayas Department, Ecuador. \\
\hline ROM 4572 & & Late Pleistocene, Guayas Department, Ecuador. \\
\hline MHN-UNSL-GEO-V 199 & & Late Pleistocene, Uspara Formation, Pasos Malos, Merlo, San Luis, Argentina. \\
\hline MCL 4265 & \multirow[t]{5}{*}{ C. cuvieri } & Late Pleistocene, Iraquara, Brazil. \\
\hline MCL 4259 & & Late Pleistocene, Gruta do Túnel, Santana, Brazil. \\
\hline MCL 22682 & & Pleistocene, Brazil. \\
\hline MCL 22683 & & Pleistocene, Brazil. \\
\hline ZMUC 1668 & & Late Pleistocene, Lapa Grande de Genette, Minas Gerais, Brazil. \\
\hline
\end{tabular}

TABLE 3. Mean of the measurements of the skulls from the two morph types of dorsal crests of Scelidotherium leptocephalum and Catonyx tarijensis. $( \pm)$ is standard deviation. $\left(^{*}\right)$ indicate significant differences in the medians with a Kruscal-Wallis Test $(p<0.05)$.

\begin{tabular}{|c|c|c|c|}
\hline Taxa & Variable & Measurements & p values \\
\hline \multirow{4}{*}{ S. leptocephalum } & LCM & $\times 477,37( \pm 55,10)$ & 0,581 \\
\cline { 2 - 4 } & LDS & $\times 102,1( \pm 10,94)$ & 0,900 \\
\cline { 2 - 4 } & MWP & $\times 99,3( \pm 9,79)$ & 0,981 \\
\cline { 2 - 4 } & WS & $\times 92,5( \pm 7,96)$ & 0,957 \\
\cline { 2 - 4 } & HS & $\times 115,24( \pm 13,51)$ & 0,676 \\
\cline { 2 - 4 } & OMf5L & $\times 254,9( \pm 29,91)$ & 0,352 \\
\cline { 2 - 4 } & WB & $\times 103,3( \pm 10,30)$ & 0,828 \\
\hline \multirow{5}{*}{ C. tarijensis } & LCM & $\times 508,8( \pm 31,02)$ & 0,603 \\
\cline { 2 - 4 } & LDS & $\times 126,56( \pm 7,78)$ & 0,263 \\
\cline { 2 - 4 } & MWP & $\times 97,89( \pm 7,80)$ & 0,999 \\
\cline { 2 - 4 } & WS & $\times 109,00( \pm 8,44)$ & 0,111 \\
\cline { 2 - 4 } & HS & $\times 124,75( \pm 9,32)$ & 0,317 \\
\cline { 2 - 4 } & OMf5L & $\times 290,13( \pm 7,49)$ & 0,984 \\
\cline { 2 - 4 } & WB & $\times 119,8( \pm 4,19)$ & 0,968 \\
\hline
\end{tabular}

the two anonymous reviewers have certainly improved the manuscript.

\section{REFERENCES}

Ameghino, F. 1889. Contribución al conocimiento de los mamíferos fósiles de la República Argentina. Actas de la Academia Nacional de Ciencias de Córdoba, 6:1-1027.

Ameghino, F. 1891. Mamíferos y aves fósiles argentinas. Especies nuevas, adiciones y correcciones. Revista Argentina de Ciencias Naturales, 1: 240-259.

Ameghino, F. 1904. Nuevas especies de mamíferos cretáceos y terciarios de la República Argentina. Anales de la Sociedad Científica Argentina, 56-71: 225-291.
Anonymous, 1827. The Zoological Journal (London), 3:140-143.

Barden, H.E. and Maidment, S.C.R. 2011. Evidence for sexual dimorphism in the Stegosaurian dinosaur Kentrosaurus aethiopicus from the Upper Jurassic of Tanzania. Journal of Vertebrate Paleontology, 31:641-651.

Brandoni, D., Ferrero, B.S., and Brunetto, E. 2010. Mylodon darwini Owen (Xenarthra, Mylodontinae) from the Late Pleistocene of Mesopotamia, Argentina, with remarks on individual variability, paleobiology, paleobiogeography, and paleoenvironment. Journal of Vertebrate Paleontology, 30:1547-1558. 
Cartelle, C. and Bohórques, G.A. 1982. Eremotherium laurillardi Lund, 1842. Parte I. Determinaço especifica e dimorfismo sexual. Iheringia, Série Geológica, 7:45-63.

Cartelle, C., De Luliis, G., and Lopes-Ferreira, R. 2009. Systematic revision of tropical brazilian scelidotheriine sloths (Xenarthra, Mylodontoidea). Journal of Vertebrate Paleontology, 29:555-566.

Cope, E. D. 1889. The Edentata of North America. American Naturalist, 23:657-664.

Corona, A., Perea, D., and McDonald, H.G. 2013. Catonyx cuvieri (Xenarthra, Mylodontidae, Scelidotheriinae) from the late Pleistocene of Uruguay, with comments regarding the systematics of the subfamily. Journal of Vertebrate Paleontology, 33:12141225.

Czerwonogora, A. and Fariña, R. 2013. How many Pleistocene species of Lestodon (Mammalia, Xenarthra, Tardigrada)? Journal of Systematic Palaeontology, 11: 251-263.

De luliis, G. and Cartelle, C. 1999. A new giant megatheriine ground sloth (Mammalia: Xenarthra: Megatheriidae) from the late Blancan to early Irvingtonian of Florida. Zoological Journal of the Linnean Society, 127:495-515.

Delsuc, F., Scally, M., Madsen, O., Stanhope, M.J., de Jong, W.W., Catzeflis, F.M., Springer, M.S., and Douzery, E.J.P. 2002. Molecular Phylogeny of Living Xenarthrans and the Impact of Character and Taxon Sampling on the Placental Tree Rooting. Molecular Biology and Evolution, 19:1656-1671.

Desmarest, A.G. 1804. Tableau méthodique des mammifères. Nouveau dictionnaire d'histoire naturelle, 24: 5-58.

Di Rienzo, J.A., Casanoves, F., Balzarini, M.G., Gonzalez, L., Tablada, M., and Robledo, C.W. 2012. InfoStat, versión 2012, Grupo InfoStat, FCA, Universidad Nacional de Córdoba, Argentina.

Frailey, C.D. 1986. Late Miocene and Holocene Mammals, exclusive of the Notoungulata, of the Rio Acre region, western Amazonia. Contributions in Science, Natural History Museum of Los Angeles Country, 374:1-46.

Gaudin, T.J. and McDonald, H.G. 2008. Morphology based investigations of the phylogenetic relationships among extant and fossil xenarthrans, p. 24-36. In Vizcaíno, S.F. and Loughry, W.J. (eds.), The Biology of the Xenarthra. University Press of Florida, Gainesville.

Gervais, H. and Ameghino, F. 1880. Los Mamíferos de la América Meridional. Igon Hermanos, Buenos Aires, pp. 1-225.

Gervais, P. 1873. Mémoire sur plusieurs especes de mammifères fossiles propres à l'Amérique méridionale. Mémoires de la Sociéte Géologique de France, 2:1-44.
Gervais, P. 1855. Recherches sur les mammifères fossiles de l'Amérique méridionale, p. 1-63. In Francis $L$. de Laporte de Castelnau (ed.), Animaux nouveaux ou rares recueillis pendant l'expédition dans les parties centrales de l'Amerique du Sud, de Rio de Janeiro á Lima, et de Lima au Para: executée par ordre du gouvernement francais pendant les années 1843 a 1847.

Gill, T. 1872. Arrangements of the families of mammals, with analytical tables. Smithsonian Miscellaneous Collections, 11:1-98.

Illiger, J.K.W. 1811. Prodromus systematis mammalium et avium additis terminis zoographicis utriusque classis, eorumque versione germanica. C. Salfield, Berlin, Germany.

Isaac, J.L. 2005. Potential causes and life-history consequences of sexual size dimorphism in mammals. Mammal Review, 35:101-115.

Kerr, R. 1792. The Animal Kingdom or Zoological System, of the Celebrated Sir Charles Linnaeus; Class I. Mammalia: Containing a Complete Systematic Description, Arrangement, and Nomenclature, of All the Known Species and Varieties of the Translation of That Part of the Systema Nature, as Lately Published, with Great Improvements by Professor Gmelin of Goettingen.

Kraglievich, L. 1934. La antigüedad pliocena de las faunas de Monte Hermoso y Chapadmalal, deducidas de su comparación con las que le precedieron y sucedieron. Imprenta EI Siglo Ilustrado, Montevideo, Uruguay. 1-133 pp.

Kurtén, B. 1969. Sexual dimorphism in fossil mammals. International Union of Geological Sciences, 1:226233.

Lara-Ruiz, P. and Garcia-Chiarello, A. 2005. Life-history traits and sexual dimorphism of the Atlantic forest maned sloth Bradypus torquatus (Xenarthra: Bradypodidae). Journal of Zoology, 267:63-73.

Latham, J., and H. Davies. 1795. Faunula indica. Appendix to Forster, J.R. Zoologia indica, Ed. Secunda. Gebauer, Halle, 38 pp.

Lund, P.W. 1839. Extrait d'une letter de M. Lund, écrite de Lagoa Santa (brésil), le 5 novembre 1838, et donnant un aperçu des espèces de mammifères fossiles qu'il a découvertes au Brésil. Comptes Rendus de l'Académie des Sciences, 8:570-577.

Lund, P.W. 1842. Blik paa Brasiliens dyreverden for sidste jordomvaeltning. Fjerde afhandling: fortsaettelse af pattedyrene. Det Kongelige Danske Videnskabernes Selskabs Skrifter: Naturvidenskabelige og Mathematiske Afhandlinger, 9:137-208.

Lydekker, R. 1886. Description of three species of Scelidotherium. Proceedings of the Zoological Society of London, 32:491-498.

McDonald, H.G. 2006. Sexual dimorphism in the skull of Harlan's ground sloth. Contributions in Science, Natural History Museum of Los Angeles Country, 510:19. 
McDonald, H.G. and Perea, D. 2002. The large Scelidothere Catonyx tarijensis (Xenarthra, Mylodontidae) from the Pleistocene of Uruguay. Journal of Vertebrate Paleontology, 22:677-683.

Miño-Boilini, A.R. 2012. Sistemática y evolución de los Scelidotheriinae (Xenarthra, Mylodontidae) cuaternarios de la Argentina. Importancia bioestratigráfica, paleobiogeográfica y paleoambiental, Unpublished Thesis. Facultad de Ciencias Naturales y Museo Universidad Nacional de La Plata, La Plata, Buenos Aires, Argentina.

Owen, R. 1839. Fossil Mammalia (3). In The Zoology of the voyage of H.M.S. Beagle (C. Darwin., editor). Simth. Elder and Co., 65-80.

Owen, R. 1840. Fossil Mammalia (4). In The Zoology of the voyage of H.M.S. Beagle (C. Darwin., editor). Simth. Elder and Co., 80-111.

Prothero, D. and Raymond, K. 2008. Variation and sexual size dimorphism in pleistocene ground sloths (Xenarthra). New Mexico Museum of Natural History and Science Bulletin, 42:331-333.

Pujos, F.2000. Scelidodon chiliensis (Mammalia, Xeanrthra) du Pleistocene terminal de "Pampa de los Fósiles" (Nord-Pérou). Quaternaire, 11:197-206.
Pujos, F., Gaudin, T.J., De luliis, G., and Cartelle, C. 2012. Recent Advances on Variability, Morpho-Functional Adaptations, Dental Terminology, and Evolution of Sloths. Journal Mammalian Evolution, 19:159169.

Ralls, K. 1977. Sexual dimorphism in mammals: avian models and unanswered questions. The American Naturalist, 111:917-938.

Rose, K.D. and Gaudin, T.J. 2010. Xenarthra and Pholidota (Armadillos, Anteaters, Sloths and Pangolins). Encyclopedia of Life Sciences (ELS), John Wiley and Sons, Ltd: Chichester.

Smith, K.M. and Fisher, D.C. 2013. Sexual dimorphism and inter-generic variation in Proboscidean tusks: multivariate assessment of american mastodons (Mammut americanum) and extant African elephants. Journal Mammalian Evolution, 20:337-355.

Squarcia, S.M., Sidorkewicj, N.S., Camina, R., and Casanave, E.B. 2009. Sexual dimorphism in the mandible of the armadillo Chaetophractus villosus (Desmarest, 1804) (Dasypodidae) from northern Patagonia, Argentina. Brazilian Journal Biology, 69:347-352.

Stock, C. 1917. Further observations on the skull structure of mylodont sloths from Rancho La Brea. University of California Publications, Bulletin of the Department of Geology, 10:165-178. 